\title{
Chemical technology of cellular glass production
}

\author{
Emma Saakyan*, Artavazd Arzumanyan ${ }^{* *}$ and Gagik Galstyan ${ }^{* * *}$ \\ National University of Architecture and Construction of Armenia, Yerevan
}

\begin{abstract}
Cellular glass by its composition, structure and technical parameters is a high-performance multifunctional material, and its use in construction and engineering is extremely important.

The problem of developing cellular glass power consumption technology on the base of natural amorphous aluminosilicates and silica rocks in a single technological process, combining the synthesis of a given glass composition and the formation of its cellular structure is solved by introduction of a nanodispersed modifier into the rock and by the mechanical activation of the charge, creating an impact possibility in the system at the atomic-molecular level.

With the involvement of a complex modern theoretical and experimental methods, the processes of glass wool rock modifyed sintering and expanding were investigated, which served as a base for creating the cellular glass technology in the form of products and granules.

The study of the secondary glass synthesis dynamics during sintering of volcanic glasses with sodium hydroxide solution showed that the hydrated amorphous neoplasms of sodium silicates synthesized at low temperatures and silica aluminosilicates with temperature rise gradually enriched with silica and formed hydrated secondary glasses, the dehydration of which expanded the mass upon reaching the pyroplastic state.

Power consumption technologies of the new type cellular glasses based on the volcanic glass-wool and other amorphous silicate rocks, which allow to combine the processes of synthesis of low-melting glass and its expansion by sintering are challenging for the production and for application in construction and engineering.
\end{abstract}

\section{Introduction}

Modern methods of industrial construction of residential and industrial facilities require a significant improvement in the quality of building materials, providing reliable thermal protection, efficiency, environmental cleanliness, seismic resistance, comfort, etc. This can be achieved with the implementation of the production technology of the cellular glass based on volcanogenic glassy rocks of silicate and aluminosilicate composition (perlite, pumice, tuff, etc.) and Armenia is rich in this materials. As a result of maximum use of this raw material potential of specific natural properties, it is possible to obtain valuable and relevant products of relatively low manufacturing cost.

\footnotetext{
* Corresponding author: emma_rubenowna@mail.ru

** Corresponding author: artavazd@inbox.ru

${ }^{* * *}$ Corresponding author: info@ nuaca.am
} 
Cellular glass (foamglass) is characterized by high physical and mechanical, thermal and physical characteristics. As a thermal insulation material, it is used in all areas of construction, in high and low temperature techniques, in the chemical industry and energetics, as a decorative and acoustic material, aggregates for artificial conglomerates (lightweight concrete, cryogenic materials), in shipbuilding and communications, etc.

In industrialized countries, foam glass is recognized as the best insulating material for use in construction and various industries. For more than 70 years Corning has been manufacturing Foamglas products in the USA, and in nowdays in four different plants of Europe. Enterprises in Japan and China are successfully operating, there are enterprises in Belarus and Ukraine as well.

The products of Foamglas are shipped to various countries, including Russia and Kazakhstan at very high prices.

The high cost of foam glass compared to the cheap non-durable and environmentally unsound foams mainly determines the influx of the latter into the construction as insulating materials. In this situation, the relevance of reducing the manufacturing cost of the cellular glass is undoubted.

Traditionally, specially welded glass is used in the production of the cellular glass, which is associated with significant power consumption, capital investments in the construction of glass furnaces and labor costs.

In this regard, the exclusion of the glass manufacturing process, the replacement of artificial glass with a cheaper alternative material in this production - glass wool, is one of the rational ways to reduce material and power consumption in the production of cellular glasses, and hence the reduction of the manufacturing cost of the material.

\section{Methodology and Results}

Researchers [1-3] suggest that in the structure of acidic volcanic glasses, and in particular in perlite, which is formed from magma and its composition was close to that of eutectic mixtures of quartz and alkaline feldspar, contains aluminosilicate and siliceous framework "motifs", which are differentiated by crystallization of lava rocks: quartz, feldspars, some zeolites. The content of volcanic glass in pearlite reaches $96 \ldots 97 \%$, while in other rocks it is less.

By prolonged isothermal heating of Aragats perlite sample at a temperature of $790^{\circ} \mathrm{C}$, we were able to identify albite, orthoclase, and cristobalite in its structure by radiometric and optical methods. This proves the identity of the composition of ordered regions in perlite glass with the composition of differentiate minerals, i.e. the short-range order in the structure of glass which is a base on which the long-range crystal chemical order in the structure of solid silicates were formed. The identical refractive characteristics of perlite glass and glass from crystallized material also indicated the identity of the composition of perlite and crystallized material [4].

The cone softening temperature, which is cut out from the Aragats perlite rock is $1170^{\circ} \mathrm{C}$, and the dilatometric temperature of the initial deformation is $\mathrm{T}_{\mathrm{f}}=960^{\circ} \mathrm{C}$, similarly, for the Jraber perlite the initial cone softening temperature is $1180^{\circ} \mathrm{C}$ and $\mathrm{T}_{\mathrm{f}}=960^{\circ} \mathrm{C}$.

The survey for ways to create less power-intensive technologies for a number of traditional materials of cellular glass and chemically resistant glass conglomerates based on volcanic rocks leads to the development of more light-melting compositions for producing these materials [5, 6]. By modifying the volcanic rock with sodium hydroxide, it was possible to significantly reduce the temperature of the initial deformation of the new glass composition. Depending on the amount of the introduced $\mathrm{NaOH}(6 \quad \ldots 12 \%)$, the deformation temperature decreased from $690^{\circ} \mathrm{C}$ to $620^{\circ} \mathrm{C}$ and the expansion temperature from $760^{\circ} \mathrm{C}$ to $950{ }^{\circ} \mathrm{C}$ with an exposure time from 5 to 50 minutes. 
The study of the sintering kinetics in the system of alkaline aluminosilicates - silica sodium hydroxide revealed the nature of the influence on the process of the type and amount of reacting components, the surface of their contact, the temperature and speed of its growth, the thermal past of the sinters.

According to the degree of activity during solid-phase sintering with sodium hydroxide, the volcanic rocks are arranged in the following series: Jraber perlite, Aragats perlite, Aghavnatun tuff, Oktemberyan tuff, Aragats obsidian, Artik's tuff, microkkin [7]. A higher interaction rate of perlite glass compared with tuffs results in lower expansion temperatures and a lower density of perlite-based cellular glasses.

The interaction of sodium hydroxide with volcanic glasses and the synthesis of a new glass composition were estimated by a thermodynamic method [8.9].

The validity of considering a mixture of volcanic glass - sodium hydroxide as a particular system of $\mathrm{SiO}_{2}-\mathrm{NaOH}, \mathrm{R}_{2} \mathrm{O} \cdot \mathrm{Al}_{2} \mathrm{O}_{3} \cdot 6 \mathrm{SiO}_{2}-\mathrm{NaOH}$ has been established. The theoretical and experimental study of these systems made it possible to determine the silicate formation reaction enthalpies, which are predominantly negative. In the area, which is rich in silica and aluminosilicate, the most stable compounds are silicates and aluminosilicates.

The study of the secondary glass synthesis dynamics during sintering of volcanic glasses with sodium hydroxide solution showed that, at low temperatures, mainly hydrate amorphous neoplasms of sodium silicates and silica aluminosilicates are synthesized, which gradually enriched at high temperatures with silica and formed chemically resistant secondary glasses.

Sodium hydroxide is introduced into the mixture in the form of an aqueous solution. Water is a necessary component and a mixture homogenizer. In its presence, diffusion and mass transfer of reactants and reaction products is facilitated: it is a part of hydrated tumors and dehydration upon reaching the pyroplastic state which expands the mass.

The ultimate gas-generating effect in the perlite-alkaline mixture is the part of water, which forms hydrogen bridging compounds with a relatively weak bound hydroxide of the first type center $\left(3460,3350 \mathrm{~cm}^{-1}\right)$. Analysis of the intensity of the absorption bands shows that, in accordance with the calculated parameters of $(\mathrm{OH}) \mathrm{n}$ - intensity of the maximum at $3600 \mathrm{~cm}^{-1}$ are the bonds of water molecules as the most strongly bound water, which decreases gradually and remains in the temperature range of expansion [10]. By introducing an additional gasifier, it is possible to adjust the nature of the cellular glass porosity, thereby changing its ways of application.

The introduction of a foaming agent $(\mathrm{C}, \mathrm{Si} \mathrm{C})$ allows to obtain cellular glasses with an average density of $100 \ldots 500 \mathrm{~kg} / \mathrm{m}^{3}$ and a coefficient of thermal conductivity of $0.04 \ldots$ $0.14 \mathrm{~W} /(\mathrm{m} \cdot \mathrm{K})$, with significant compressive strength of $0.6 \ldots 10 \mathrm{MPa}$, with an operating temperature application of $-164+645^{\circ} \mathrm{C}$. The above mentioned values characterized the obtained cellular glass as a cold and heat insulating material.

The structure formation of spongy cellular glasses were investigated and their acoustic properties were determined [11]. The sound absorption coefficient of decorative blocks of cellular glass in the frequency range of $125 \ldots 4000 \mathrm{~Hz}$ is $0.43 \ldots 0.88$, and the reverberation coefficient of sound absorption of bulk sound absorbers from cellular glass granules of $5 \ldots 10$ and $10 \ldots 20 \mathrm{~mm}$ in the frequency range of $500 \ldots 8000 \mathrm{~Hz}$ is respectively $0,31 \ldots 0.78$ and $0.32 \ldots 0.66$.

A chemically resistant cellular glass with an average density of $400 \mathrm{~kg} / \mathrm{m}^{3}$, compressive strength of $10 \mathrm{MPa}$, and acid resistance of $99.9 \%$ [12] and a high-temperature (up to $1000^{\circ} \mathrm{C}$ ) chemically resistant with an average density of $200 \ldots 500 \mathrm{~kg} / \mathrm{m}^{3}$, compressive strength of $3 \ldots 7 \mathrm{MPa}$ has been developed, with thermal conductivity coefficient at temperatures: $25^{\circ} \mathrm{C}-0.081 \ldots 0.132,300{ }^{\circ} \mathrm{C}-0.135 \ldots 0.187,600{ }^{\circ} \mathrm{C}-0.196 \ldots 0.247 \mathrm{~W} /$ $(\mathrm{m} \cdot \mathrm{K}),[13]$. The pores are closed $(0-3 \%)$ and are inaccessible for the liquid and gas 
penetration, the structure is uniform, fine-porous. Spheres of application are chemical, metallurgical, construction industries, etc.

Table 1. Characteristic of cellular glass.

\begin{tabular}{|c|c|c|c|c|c|c|}
\hline \multirow[b]{2}{*}{ Indicators } & \multicolumn{2}{|c|}{ Cellular glass } & \multicolumn{4}{|c|}{ Granulate of cellular glass } \\
\hline & $\begin{array}{l}\text { thermal } \\
\text { insulating }\end{array}$ & acoustic & $\begin{array}{l}\text { Extra light } \\
\text { thermal } \\
\text { insulating }\end{array}$ & $\begin{array}{l}\text { Extra light } \\
\text { acoustic }\end{array}$ & $\begin{array}{l}\text { Light thermal } \\
\text { insulating }\end{array}$ & $\begin{array}{c}\text { concrete } \\
\text { aggregate }\end{array}$ \\
\hline Density, $\mathrm{kg} / \mathrm{m}^{3}$ & & & & & & \\
\hline average & $100 \ldots 450$ & $100 \ldots 300$ & $100 \ldots 150$ & $100 \ldots 150$ & $160 \ldots 390$ & $400 \ldots 450$ \\
\hline bulk & - & - & $60 \ldots 100$ & $60 \ldots 100$ & $120 \ldots 240$ & $250 \ldots 300$ \\
\hline $\begin{array}{l}\text { Strength limit, } \\
\qquad \mathrm{MPa} \\
\text { at compression } \\
\text { when squeezed } \\
\text { in the cylinder }\end{array}$ & $\begin{array}{c}0,6 \ldots 10,0 \\
-\end{array}$ & $\begin{array}{c}0,6 \ldots .5,0 \\
-\end{array}$ & $\begin{array}{c}- \\
0,15 \ldots 0,70\end{array}$ & $\begin{array}{c}- \\
0,15 \ldots 0,70\end{array}$ & $\begin{array}{c}- \\
0,7 \ldots 1,5\end{array}$ & ${ }^{-}$ \\
\hline $\begin{array}{c}\text { Water } \\
\text { absorption, \% }\end{array}$ & $0 \ldots 10$ & $60 \ldots 80$ & $5 \ldots 30$ & $60 \ldots 80$ & to 5 & to 5 \\
\hline $\begin{array}{l}\text { Coefficient of } \\
\text { thermal } \\
\text { conductivity, } \\
\mathrm{W} /(\mathrm{mK})\end{array}$ & $0,040 \ldots 0,146$ & - & $0,030 \ldots 0,041$ & - & $0,040 \ldots 0,060$ & $0,066 \ldots 0,080$ \\
\hline $\begin{array}{c}\text { Sound } \\
\text { absorption } \\
\text { coefficient at a } \\
\text { frequency of } \\
120-4000 \mathrm{~Hz}\end{array}$ & - & $0,20 \ldots 0,88$ & - & $0,31 \ldots 0,78$ & - & - \\
\hline $\begin{array}{l}\text { TCLE in the } \\
\text { range of } 30- \\
300^{\circ} \mathrm{C}, 10^{-7}{ }^{\circ} \mathrm{C}\end{array}$ & $70 \ldots 72$ & 72 & 72 & 72 & 70 & 70 \\
\hline $\begin{array}{c}\text { Heat } \\
\text { resistance, } \mathrm{C}\end{array}$ & $300 \ldots 430$ & 300 & 400 & 400 & 400 & $300 \ldots 400$ \\
\hline $\begin{array}{l}\text { Temperature } \\
\text { resistance, }{ }^{\circ} \mathrm{C}\end{array}$ & $600 \ldots 650$ & $600 \ldots 650$ & $600 \ldots 650$ & $600 \ldots 650$ & $600 \ldots 650$ & $600 \ldots 650$ \\
\hline $\begin{array}{l}\text { Hydrolytic } \\
\text { class }\end{array}$ & II...III & - & III...IV & - & II...III & II....III \\
\hline $\begin{array}{c}\text { Frost } \\
\text { resistance, } \\
\text { the number of } \\
\text { cycles }\end{array}$ & more than 20 & - & - & - & more than 50 & more than 50 \\
\hline
\end{tabular}

According to the developed technology, we have obtained cellular glasses, including granulated raw materials from the Far East and the North of the Russian Federation. Granulated cellular glass was obtained from the Transbaikal perlites of the Kholinsky field at expanding temperature of $750 \ldots 850{ }^{\circ} \mathrm{C}$, for thermal insulation purposes and characterized by a bulk density of $160 \ldots 300 \mathrm{~kg} / \mathrm{m}^{3}$ and water absorption of $1.5 \ldots 3.5 \%$ for use in packing-blocks for channelless pipelines, for acoustic applications, which is characterized by open porosity up to $60 \%$ at a density of $110 \ldots 170 \mathrm{~kg} / \mathrm{m}^{3}$ [14]. 
Cellular glasses with an average density of $200 \ldots 400 \mathrm{~kg} / \mathrm{m}^{3}$ were obtained under the expansion temperature range of $800 \ldots 820^{\circ} \mathrm{C}$, with compression strength of $1.1 \ldots 8.2 \mathrm{MPa}$, water absorption capacity of $0.8 \ldots 6.4 \%$ by volume, with thermal conductivity coefficient of $0.041 \ldots 0.06 \mathrm{~W}(\mathrm{~m} \cdot \mathrm{K})$, temperature resistance of $650 \ldots 700{ }^{\circ} \mathrm{C}$ from the Tyumen sedimentary rocks, diatomites, crusts, triplex, and Inze diatomites with a modification with from 13.8 to $17.8 \% \mathrm{NaOH}$ and an additional blowing agent [15.16.].

Cellular glass with an average density of $250 \ldots 500 \mathrm{~kg} / \mathrm{m}^{3}$ and cellular glass granulate with a bulk density of $150 \ldots 300 \mathrm{~kg} / \mathrm{m}^{3}$ with a volumetric water absorption of up to $2.3 \ldots$ $5 \%$ were obtained on the base of quartz sand and cullet with a ratio of quartz/cullet $-1 / 4$ [17].

Similar developments have been carried out with Semipalatinsk vitrafirs (Kazakhstan), the technical documentation for the project of a plant of a granular variety of which we called semizite, was issued. Characteristics of semizite are: bulk density of $150 \ldots 350$ $\mathrm{kg} / \mathrm{m}^{3}$, thermal conductivity coefficient of $0.05 \ldots 0.07 \mathrm{~W}(\mathrm{~m} \cdot \mathrm{K})$, water absorption capacity from 1 to $9 \%$.

Differentiated approach to the type of raw materials and directional selection of technological operations providing management of cellular materials, allow us to obtain materials with high performances.

Artificial conglomerates were obtained on the base of granular cellular glasses with cement, gypsum, limestone, dolomite, liquid glass, etc. in the form of dense and porous arrays and products of any configurations for use in building and industrial heat and cold insulation, etc. $[18,19,20]$.

\section{Discussion}

Due to the interaction of amorphous silicate and aluminosilicate rocks with sodium hydroxide solution, hydrated newly formed particles of silicates are formed, which are made of monomeric sodium cations and nanoscale polymeric silicon-oxygen anions.

With a rise in furnace processing temperature, hydrated silicate and aluminosilicate compounds are synthesized in the mixture, the dehydration of which expands the glass.

The technology of glass material through the synthesis of newly formed particles at all stages of the process with nanoscale particles is actually nanotechnology.

By adjusting the composition of the mass and the selection of technological parameters, cellular glasses of various purposes with high physical and mechanical parameters were obtained.

Production of various cellular glasses using energy-saving technology based on natural silicate and aluminosilicate amorphous rocks makes it possible to combine the formation of a given glass composition and the formation of its cellular structure in a single technological process, thereby eliminating the need for preliminary glass melting.

\section{Conclusion}

The traditional use of specially welded glasses in the cellular glass production, leads to significant power manufacturing costs, an increase in capital investments and labor. In this regard, an undoubted interest is the development of power consumption technologies of new types of cellular glasses based on volcanic glass wool and other silicate and aluminosilicate rocks according to the technology, which allows to combine processes of sintering the synthesis and expansion of fusible-glass.

The development of a method for modifying the mentioned types of rocks and synthesizing new metastable phases, which are capable to expand during sintering, cellular 
glasses are produced with a wide range of density characteristics - strength, thermal conductivity, application temperature, porosity, etc., which are distinguished by environmental safety and durability.

\section{References}

1. Perlite and vermiculite //Ed. V.P. Petrov -M.: Gosgeoltekhizdat 1962, -123p.

2. N.S. Manuylova et al. // Collection of papers ROSNIISM-1962, N24, -. 32-45 p. and 46-53p. 2.

3. S.P. Kamenetsky. Perlites.-M.: Gosstroyizdat, 1963, 270p.

4. Sahakyan E.R., Akopyan R.V., Gevorkyan S.V. // Inorganic materials. -1970, v.6, N10, 1901-1902p.

5. Sahakyan E.R. // New artificial cellular materials, lightweight aggregates and products on their base: Author's abstract of scientific paper. M., 1992. -32p.

6. Yazychyan R.N. // Chemical journal of Armenia.-2000.-v.53, N3-4, 111-117p.

7. Mtschedlow-Petrossian O.P.,Saakyan E.R.//Silikattechnik. 1988.-Bd.39,N6 -s. 189-190.

8. Frenkel B.I., Matveev, G.M., Sahakyan, E.R. // JPCh.1973. v. N11, 2421-2434p.

9. Sahakyan ER. // Tr. NIIKS-Yerevan, 1975.-Vol. 8, -p 203-212.

10. Bakhchisaraytseva S.A., Sahakyan E.R. // Inorganic materials, 1971 -v.7, N11 -20572060p.

11. Sahakyan E.R. // Glass and ceramics, 1991, N1, 5-6p.

12. Yazychyan R.N. // Chemically resistant silicate building materials based on volcanic rocks. Abstract of Ph.D. Yerevan, PI, 2002, 21p.

13. Sahakyan E.R.// Pat. RA N3118A "Production methods foam" 03.07.2017, from 04 B38 / 00

14. Sahakyan E.R. // Glass and ceramics, 1990, N2, p.7.

15. Sahakyan E.R. // Glass and ceramics, 1991, N3, p.3-4.

16. Sahakyan E.R, Meliksetyan G.A.// Proceedings of Yerevan state university of architecture and construction, v.3(42), 115-120p.

17. Sahakyan E.R, Meliksetyan G.A. // All-Russian Journal of Scientific Publications, M., N8, 2011, 78-80p.

18. 18. Putlyaev I.E., Davidyuk A.I., Saakyan E.R, Arutyunyan M.R. // Industrial Construction, -1990, N11, 1p.

19. Ter-Petrosyan P.H.,Sahakyan E.R., Zakaryan G.L.// Proc.of the 3-rd Internat. Conf.on Contemp.probl.in Architekture and Construction.-2011-Beijing, China.

20. Ter-Petrosyan P.A., Saakyan E.R., Voskanyan A.L., Voskanyan R.L.// Concrete Technologies, 2006, N2, 12-14 p. 